\title{
How do southern Spaniards create the conditions necessary to initiate negotiations with strangers?
}

\begin{abstract}
Based on focus group discussions and interviews with Spanish-speaking business people experienced in negotiations with Spaniards this paper focuses on what they say about their first time business meetings with southern Spaniards. The informants include both non-Spaniards and Spaniards, the last group comprising both Spaniards from the northern and the southern parts of Spain. Thus foreigners and northern Spaniards talk about their experience related to first time business meetings with southern Spaniards, whereas the southern Spaniards reflect on how they see themselves in first time meetings with business people from other parts of Spain and from abroad. Special attention is given to how the informants describe the start-up phase of their business relations. The paper introduces different theoretical approaches to such first time intercultural meetings - including a sociological approach, the approach offered by intercultural communication, and Face theory - and based on the key concepts of these approaches the paper discusses to what extent the businessmen involved draw on concepts related to the theories in their sensemaking effort.
\end{abstract}

\section{Introduction}

Worldwide there is an increasing need to understand the mechanisms that come into play when people from different cultures meet in order to interact. There has been a large number of different theoretical approaches to this question in different contexts, but this paper will draw on the ones that offer some kind of framework for understanding what happens between strangers who intend to do business together.

After a brief look at a sociological approach drawing specifically on Oliver F. Williamson and his continuum of possible ways of initiating the interaction between strangers, I shall turn to intercultural commu-

\footnotetext{
* Anette Villemoes

Department of Frensh, Italian, Russian, Spanish, and German Copenhagen Business School

DK-2000 Frederiksberg
} 
nication to see what Gudykunst et al. offer as an explanation of what goes on in the first time encounters between strangers, and what they suggest as a means of commencing the interaction. Whereas Williamson talks about trust as a means to establish a relationship, the intercultural communication scholars talk about the importance of reducing the levels of uncertainty and anxiety, characteristic of first time encounters between strangers. What they advocate is studying the unknown culture as the appearance of cultural patterns will help foresee the reactions of the other party, thereby reducing uncertainty and anxiety enough to allow for the interaction to begin. The concept of trust central to the sociological approach seems to come in many guises heavily influenced by the surrounding culture, which leads me to introduce the concept of trust in its Spanish variety, i.e. confianza. After a brief introduction to the above mentioned theories related to meetings between strangers the paper goes on to discuss what is actually said about the experience by people playing the role of the stranger in such meetings involving southern Spaniards. Finally, the extent to which the stories told by the informants relate to the theoretical frameworks introduced will be discussed. The businessmen involved had no systematic theoretical knowledge of interaction processes between strangers in intercultural settings.

Before introducing the theoretical approaches I shall give an outline of the empirical data on which the findings are based.

\section{Empirical data}

In 1998, in collaboration with Esade and the Vienna Wirtschaftsuniversität, I got together with a colleague of mine at the Copenhagen Business School to try and produce some teaching material that would help foreigners cope with Spanish negotiators. Our task was first and foremost of a pedagogical nature.

In order to get an idea of how foreign negotiators looked at Spanish negotiators and vice versa we organized a series of interviews with businessmen experienced in negotiating in a Spanish setting. We, or rather a number of colleagues from Esade, organized the interviews with a Turk, an Englishman, an Italian and a Frenchman together with four Spaniards that characterize themselves as Andalusian, Spanish and (two) Catalan, respectively. The interviews were in-depth interviews of about one hour's duration, and they were conducted according to a semi-structured inter- 
view guide. So, one part of our empirical material consists in about eight hours of interviews with people that have a lot of experience from actual negotiations with foreign business people, being either Spaniards themselves or non-Spaniards experienced in negotiations with Spanish business partners.

The other part of our empirical data is based on three focus group sessions, also organized by our Esade colleagues. (For a discussion of the focus group as a method for cultural analysis, see Kjærbeck: 2001). One group was made up of only experienced negotiators of Spanish nationality, one of experienced business people of only foreign nationalities, and one was a group of mixed nationality, in the sense that participants were Spanish and non-Spanish negotiators. The average number of participants in the focus groups was nine, and the average length of sessions was about one hour. There was a moderator in charge of each of the focus groups who gave an introduction to the general subject, but otherwise he allowed the participants to speak freely and introduce their own points of view, tell their own anecdotes and diverge as they pleased. The moderator only intervened if a subject seemed to be exhausted, or if the conversation seemed to be petering out.

Both interviews and focus groups were videotaped and transcribed for further study.

The main focus introduced by the interviewer and moderator, respectively, was the possible correlation between Spanish nationality and the way negotiation interaction takes place. An opening question would run as follows: "How would you characterize a Spaniard as a negotiator?" or something to that effect.

In the material there is a clear indication that the people involved, both Spaniards and non-Spaniards, react strongly to the hypothesis underlying a question of this type. Generally they do not accept nationalities as a homogenizing factor:

Cuando estoy pensando qué es la diferencia por ejemplo entre españoles e ingleses siempre hay varias características que dicen que los españoles tienen, pero cada vez pienso yo conozco tanta gente en Inglaterra con las mismas características.

When I think of the differences for instance between Spaniards and Englishmen, there are always a number of characteristics that you could 
attribute to the Spaniards, but then I always think that I know just as many Englishmen with the very same characteristics.

And they find it especially hard when talking about Spain:

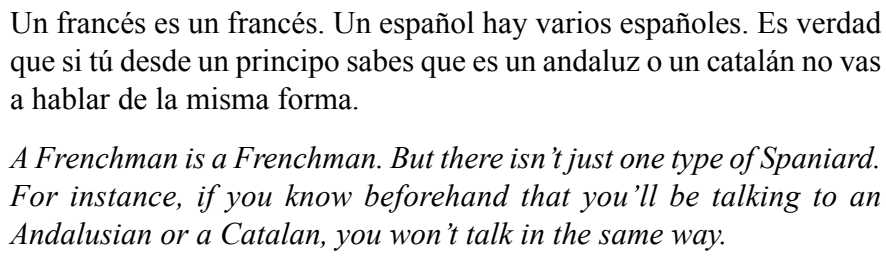

To make a long story short, all the people involved in the interviews and focus groups, both Spaniards and non-Spaniards, seem to agree that, in spite of the dangers inherent in all generalizations, it is acceptable in this context, i.e. in relation to negotiation behavior, to see Spain as two Spains, viz.

- The northern part of Spain, from north of Madrid and upwards, Catalonia being the prototypical representative of this part

- The southern part of Spain, i.e. Madrid and downwards, with Andalusia as the prototypical representative of this part of Spain.

All informants seem to agree that in order to capture the essence of the southern way of negotiating in Spain another limitation must be observed as well: what the informants characterize as the southern way of negotiation applies exclusively to the so-called Pymes, i.e. small and medium sized enterprises often operating on a local basis as opposed to large scale international businesses. So from this point on the paper will take into account both the apparent consensus about the two Spains into which Spain seems to divide itself and the importance of size and operational scope of the business involved. When talking about the ways in which Spaniards prefer to negotiate, in the following I shall focus ONLY on the southern part of Spain as defined above and ONLY on negotiations as they take place in small and medium sized enterprises in this part of Spain.

\section{Theoretical approaches}

The situation that we asked the interviewees and focus group participants to relate to is a situation with the following characteristics: Two interlocutors or two groups meet for the first time in order to reach an agreement 
about some specific project or deal. So the focus is on a first time international business encounter between strangers, one of the negotiators being from southern Spain. Below a number of theoretical approaches to such first time intercultural encounters are presented.

\subsection{A sociological approach: Trust}

According to the sociologist Oliver F. Williamson (1993) the key to open up negotiations or interaction of any kind between strangers is trust. To Williamson trust can be seen as a continuum with the ideal interpersonal trust characteristic of true friendship at one extreme, followed closely by the realistic trust characteristic of 'normal' friendship, and at the other extreme of the continuum we find codified trust characteristic of a contractual relationship. So the interlocutors can choose to build the deal on relations based on an almost religiously non-calculative trust, on normal down-to-earth friendship-like relationships of a calculative nature, and finally, on institutionalized contracts that vest the trust in the legal system. Either you trust the person that you have no reason to trust - you only just met him - and take the risk involved, or you place your trust in the system and draw up a contract that you hope will foresee all contingencies. The friendship end of the continuum means taking a risk by exposing yourself to the whims of the other party - and this applies both ways. In other words, you lose control of the situation, but trust enables the two parties to act. The other end of the continuum is characterized by lack of interpersonal trust, but the apparent control embedded in the formal contract also enables the two parties to act.

\subsection{An intercultural communication approach: Reduction of uncertainty and anxiety}

The situation that the businessmen in the focus groups and interviews refer to could also be termed intercultural communication or communication in intergroup or interpersonal contexts in which the parties see each other as strangers (Simmel: 1950). According to Gudykunst and Hall (1994: 229) interaction with strangers is characterized by high levels of uncertainty and anxiety, uncertainty referring to our cognitive ability to predict and/or explain strangers' feelings, attitudes, values, and be- 
124

havior, and anxiety involving our affective or emotional reaction to communicating with strangers.

So in order to negotiate effectively with strangers uncertainty reduction becomes a major issue in intercultural communication. According to Gudykunst \& Kim (1992: 256) there are two types of uncertainty that are relevant when we communicate with strangers: predictive and explanatory uncertainty. Predictive uncertainty involves the degree to which we can predict strangers' attitudes, beliefs, feelings, values, and behavior. Explanatory uncertainty, in contrast, involves the degree to which we can accurately explain why they behave the way they do. Gudykunst and Kim isolate a number of factors that will help reduce uncertainty, among others they recommend that our expectations should be welldefined, i.e. we should study the strangers beforehand and learn as much as possible about their ways before we meet, our own social identities should be strong, and they also recommend that we look for similarities between our group and the strange group as well as for networks and other relations that we might have in common, etc. In short, they recommend that we prepare for the meeting with the strangers by studying their ways and being conscious about our own ways.

While uncertainty results from our inability to predict others' behavior, anxiety stems from the anticipation of negative consequences. Anxiety refers to the feeling of being uneasy, tense, worried, or apprehensive about what might happen. It is an affective, i.e. an emotional response. People fear at least four types of negative consequences: psychological or behavioral consequences for the self, and negative evaluations by members of the outgroup and the ingroup. Fear, of course, is a serious threat to communication, so the other major issue involved in negotiating with strangers is how to reduce anxiety. Stephan and Stephan, (1985 in Gudykunst and Hall, 1994: 229) recommend to reduce anxiety caused by intergroup interaction by interacting, i.e. prior intergroup relations are the best medicine, as getting to know each other is the best way to learn the norms that govern the other group. The ideas of Gudykunst and his followers are that as the relationship becomes more intimate there tends to be less uncertainty and anxiety involved. Thus in acquaintanceships there is less uncertainty and anxiety than in relationships with strangers, and in friendships there is less uncertainty and anxiety than in acquaintanceships. But it is hard work to get there, or, in the terminology 
of Gudykunst (1993), it takes a lot of mindfulness, not to mention the time it takes to get to a point that will allow you to reduce uncertainty and anxiety sufficiently to start the interaction.

\subsection{A social constructivist approach: The construction of self}

Gudykunst advocates preparation, both on the cognitive and the emotional level, as he believes there are some norms that, to some extent, will predict the strangers' behavior and thus allow us to get better at coping with these specific strangers. These norms, according to the functionalist approach, apply to all members of a certain group, e.g. to all members of a specific culture. But the idea that culture generates special and foreseeable behavior has been seriously questioned by the so-called social constructivists. In a constructivist perspective there is no such programming power in culture. Each individual is unique and yet has no core or essence that could be seen as that person's identity. The uniqueness of each person is his or her ability to change identity according to the necessities of the situation. We have a whole series of identities, e.g. an identity as a mother, a sister, an aunt, etc., a professional identity, an identity for when we are with some specific friends, another that we activate when we are with other friends, etc., etc. This idea takes us to the point where it makes almost no sense to talk about an identity, nor, perhaps, about identities in the plural. It almost makes more sense to see each individual as devoid of identity. And this is exactly the point of the social constructivists. They see us as persons capable of creating ourselves in the interaction with other people. We construct ourselves according to the needs inherent in each and every situation. But the self that we choose to create in a specific situation is only valid if the person that we are interacting with accepts the self that we present. According to this approach we negotiate our own identity in constant interaction with our interlocutors. If I construct myself as a trustworthy negotiator in a specific situation, I am only trustworthy if the other party accepts me as such. This way of looking at interaction has a lot in common with the concept of face introduced by Goffman (1967: 5). 


\subsection{A face approach: Specific Spanish face needs}

To Goffman face is given to the individual by the community, but only on a loan basis, because the community may take back the face given if the receiver does not respect the rules of the community. In other words, to Goffman face is a reflection of the socio-cultural context of the surrounding community, and therefore it is possible to study the characteristics of e.g. Spanish face, an approach which in this respect resembles the one advocated by Gudikunst. Following Bravo (1996, 1999), who has looked at Spanish face in business interactions, face has to do with the relation between ego and alter, and she chooses to call the two aspects autonomy (the need to see oneself/to be seen by the others as different from the group) and affiliation (the need to identify with/to be identified with the group), respectively. Based on a corpus of business interaction Bravo (1999) characterizes one special aspect of Spanish autonomy needs as the need for self-affirmation, e.g. by exhibiting originality and boasting of good personal qualities. Concerning affiliation needs Bravo sees as a special Spanish characteristic the ideal of confianza, a word that is normally translated into trust, but given the specific meaning presented by Bravo, we will distinguish between trust and confianza.

According to Bravo (1999: 172) a relation of confianza entails that you know what to expect from the other person, and you know that you can talk without fear of offending. The two needs, i.e. that of self-affirmation and confianza are connected in the sense that if you affirm yourself it is to obtain confianza or to confirm the confianza that you already enjoy. And the other way round: The confianza is renewed and confirmed by the affirmation of good qualities. These findings are corroborated by Briz (1998) in his studies of colloquial Spanish and by Hernández Flores in her doctoral thesis on politeness in Spanish conversation in family settings (2001). She elaborates on the concept of confianza which turns out to play a key role in the interviews and focus group comments in our empirical data that we will soon take a closer look at. According to Hernández Flores (2001: 89) confianza can be characterized as follows:

To have somebody's confianza means to have a close and affective relationship with someone.

To talk to somebody with confianza entails a frank and open communicative style without reservations. 
To be a person of confianza means to be very close, to know each other very well as if you were part of the family.

To do something because there is confianza means to act freely and in accordance with your own personality, without fear of offending and knowing that your acts will be naturally received.

In short, according to Hernández Flores confianza refers to a kind of social contract between people who know each other very well. It has very positive connotations on the condition that the confianza is shown in an adequate setting and to an adequate person, i.e. to a person close to you, and, finally, that it is not exaggerated. Confianza gains negative connotations if it is shown by persons who take the existence of this special social contract for granted in conditions in which the persons involved do not know each other sufficiently or are not sufficiently close.

The concept of confianza has been considered here in some detail as it turns out to be playing a pivotal role in the data analyzed.

\section{Analysis of data}

We are now going to take a closer look at how the interviewees and focus group participants characterize the behavior of southern Spaniards during first time business meetings in small and medium-sized enterprises in the southern part of Spain.

Before starting on the actual analysis it should be made clear that what is said by the persons who supply the empirical data is not necessarily the truth as such. What they say reflects their intent to make sense of their own experience as a negotiator in professional business settings, and what is said in the analysis is my intent to make sense of their utterances. It should be added, though, that the findings of the analysis are based on observations made by several interviewees and adhered to by several focus group participants, i.e. there must be a certain repetition in the observations made by the participants for me to present them here. In my analysis I am looking for general patterns in the specific interviews and focus group discussions.

As already hinted several times, the concept of confianza is referred to again and again both by Spaniards and foreigners as e.g. in the following utterances made by Spaniards:

Yo creo, como hemos dicho antes, la confianza en España es un factor decisivo. Yo creo que gran parte de la negociación se usa o se gasta en 
lograr o dar confianza o en adquirir confianza de la persona que se tiene enfrente. Es a veces bastante más importante la confianza que los datos objetivos que se están exponiendo sobre la mesa.

I think, as we have already said, that confianza in Spain is a decisive factor. I think that a lot of negotiation is spent trying to create confianza, to give confianza or to obtain confianza from the person in front of you. Some times confianza is a lot more important than the facts put forward.

Es muy importante. Cuanta más confianza hay en el adversario o en el otro partner, más efectiva es la comunicación, y más efectiva es la negociación. Si no hay confianza, se queda mucho a nivel superficial, en que hay muchas palabras y pocos acuerdos. Cuando hay más confianza, quizás hay menos palabras, pero los acuerdos son más basados en la confianza en la otra persona.

It is very important. The more confianza there is in the counterpart or in the other party, the more effective the communication will become, and the more effective the negotiations will become. If there is no confianza, everything moves at a more superficial level, there is a lot of words and very little agreement. If there is more confianza, there may be less words, but the agreements are based more on the confianza in the other person.

So there are clear indications that Hernández Flores' confianza concept is being used outside its proper realm, which was, as may be recalled, the family realm or relations where people know each other very well, and yet it still seems to do the trick as can be seen in the next quotation by a Turk:

...puedo decir que con mucha gente con la que he empezado a trabajar, ahora soy amigo. No sé si es la respuesta a su pregunta, pero es eso. Con mi abogado soy amigo. Con mis clientes soy amigo. Y necesitan eso. Necesitan también ver la gente bastante cerca. Yo creo que esta parte es lo más importante. Si no cogen confianza, si no sienten, es muy difícil hacer negocios a largo plazo con un español.

...I can say that now I'm a friend of many of the people that I started to work with. I don't know if that answers your question, but that is how it is. My attorney is a friend of mine. My clients are friends of mine now. And they need it. They also need to come quite close to people. I think that that is what is most important. If they do not feel confianza, if they don't feel, it is very difficult to do long-term business with a Spaniard.

So confianza in business settings seems to trigger friendship. But how is this ambiance of confianza and friendship staged bearing in mind that 
the two parties do not actually know each other? Judging from what is said in the interviews and the focus groups, quite a few of the characteristics of Spanish negotiation fit nicely into an ambiance of friendship rather than into one of business. E.g. friends do not spend time at the office, they prefer to go out:

Yo diría que se pone de manifiesto la informalidad y las relaciones humanas, se ponen de manifiesto cada vez que tu interlocutor quiere hablar contigo por ejemplo comiendo, o prefiere hablar contigo cenado, o en cualquier sitio que no sea la oficina. A mi me parece realmente que esto indica que se quiere crear un clima de confianza y que no se está a priori muy interesado en aspectos muy concretos, puesto que para concretar y para llevar información hace falta una oficina con ordenadores, con números, con papeles, cosas que normalmente no se usan durante una comida de trabajo.

To me what stands out is the informality and the human relations, they stand out every time your interlocutor wants to talk to you during lunch or if he prefers to talk to you during dinner or anywhere but at the office. To me this really indicates that they want to create a climate of confianza and that, a priori, they aren't that interested in specific things, because it takes an office with computers, numbers, papers, etc. to get down to business and handle information, things that you wouldn't normally find at a business dinner.

And in this informal setting, far from the computers and offices, the things discussed are not things pertaining to negotiation. They talk about football and they do it in the way that Bravo foresaw: In order to support the confianza the Spaniard turns on his charm, his self-affirmation comes into play, and he focuses his attention one hundred per cent on the interlocutor, all of which is seen by the foreigners as 'the charismatic charm of the Spaniard'.

And finally the informants seem to agree that when at some point the actual negotiation takes place the Spaniards exhibit a surprising lack of preparation, a fact which actually seems to be appreciated by the foreigners:

Pues, yo creo que el español, pues lo que es preparación quizás no la tiene tanto como otras culturas, pero es más flexible. Es bastante imaginativo, yo creo es muy dinámico, reacciona muy rápido ante cambios de planteamientos. Creo que eso es su punto fuerte ¿no? o al menos es la percepción que yo tengo. Claro, eso si se combina con preparación puede ser una combinación muy buena ¿no? porque se arriesga bastante 
yo creo el español. Asume basantes riesgos, piensa rápido, reacciona rápido.

Well, I think that maybe the Spaniard isn't so much into preparation as other cultures, but then he is more flexible. He is quite imaginative, and I think that he is very dynamic, he reacts very quickly to new situations. I think that that is his strong point, or anyway it is to me. Well, of course, if you combine this with preparation you would get a very good combination. Because I think that the Spaniard risks a lot. He takes a lot of risks, he is a quick thinker, he reacts quickly.

To sum up and make a long story very short, according to the informants the following characterization of southern Spaniards in small and medium-sized enterprises makes sense to them in spite of its obviously generalizing nature:

- The southern Spaniard in small and medium-sized enterprises when doing business prefers to negotiate in the confianza-mode. This triggers friendship which again calls for informal conversation in informal places in a very individualized way, self-affirmative behavior, creativity and imagination, flexibility, dynamism, improvisation, and lack of preparation.

\section{Practice and Theory}

We have now seen what the businessmen experienced in negotiations involving southern Spaniards seem to agree on. They concur in telling the above story. In their stories about their first time negotiations with southern Spaniards they directly or indirectly draw on the theories introduced earlier as summed up below:

- The Sociological Approach

In the stories told the persons involved agree that the southern Spaniards prefer to negotiate under conditions that could be seen as belonging to the extreme of "non-calculative trust characteristic of true friendship', i.e. the extreme of the Williamson continuum characterized by interpersonal trust. It is interesting that the preference for this extreme of the continuum seems to rule out any activity at the other extreme. Thus, the informants agree that the southern Spaniards seem to shun calculations, details, and specifications of any kind, just as they avoid taking anything down on paper, activities that would be characteristic of the other extreme, viz. the extreme of the institutionalized contract. 
- The Intercultural Communication Approach

The contributions of Gudikunst et al. to the understanding of first time meetings had to do with the reduction of uncertainty and anxiety. Their advice was to take the time and make the effort to learn about the stranger. According to the stories told by the informants, this is exactly what the southern Spaniards do not do. They deliberately take a short cut skipping the tedious and time-consuming work of studying the other culture. In an indirect way, the contributions of Gudikunst et al. are as important as are the contributions of Williamson in a direct way.

Another assumption underlying this approach is the programming power inherent in culture. This assumption is rejected by the informants on a national scale, but is accepted as relevant on a more local scale, viz. their acceptance of the concept of 'the southern Spaniard in small and medium-sized enterprises' who, according to the informants can be foreseen to behave in a specific way.

- The Social Constructivist Approach

In the stories there is an important element of construction in the sense that the friendship is a postulate and not a fact in the first time meetings. The friendship as a construction rests on feeble ground as the bluff may be called at any moment by any distrusting stranger, but the southern Spaniards nevertheless take the risk, and there are surprisingly few instances of stories about calling the bluff in the empirical data. Judging from these empirical data it could be deducted that when strangers meet and one of the parties insists that the other party is a dear friend, it takes more effort to deconstruct the friendship role than it does to accept it.

- The Face Approach

Without any prior systematic knowledge of Goffman and his face theory the informants seem to recur to his concept of face in its Spanish guise - confianza - when they look for an explanation of what goes on in the interaction with southern Spaniards. Only one basic rule of the confianza game is broken by the southern Spaniards, viz. its use outside the realm of close friendships, but the positive connotations of confianza are so alluring to the insecure and anxious stranger that 
more often than not he prefers to let himself be constructed as a dear friend.

In synthesis, it seems that the theoretical approaches presented in this paper all contribute to the overall understanding of interpersonal communication between strangers in southern Spain and that the different contributions to a large extent seem to coincide with a layman's common sense interpretation of what goes on.

\section{Conclusion}

As I hope to have shown, there is a kind of logic built into the alleged behavior of the Spaniard of southern Spain. His preferred mode of interaction is the one defined by Hernández Flores and Bravo that fits nicely on the left hand side of Williamson's continuum. This makes him a risk taker, and the risk he takes is to try and construct, in the social constructivist sense of the word, a set-up in which the stranger, as if struck by a magic wand, is suddenly turned into a close friend. He is simply treated as one, and very often the trick works: "All my best friends today are people I met through my work."

What the southern Spaniard gains this way is that all the hard work of getting to know and understand the stranger in front of him is avoided. He ventures a short cut and 'seduces' the stranger into believing that he has just found a very dear friend. And between two friends there is no need for tedious details and meticulous contracts. In social constructivist terms what happens is that the southern Spaniard in the interaction constructs a world in which business relations are turned into friendship relations. And the means that he uses is taking the confianza relation which belongs to close relations and transferring it to a context where it definitely does not belong according to the local confianza rules known to the southern Spaniard, but unknown to the stranger. And if the southern Spaniard is in luck, he will elicit the very human longing to gain a true friend. The stranger will cease to be a stranger and become a dear friend.

But sometimes the magic of the wand is not strong enough, and the stranger feels deceived and cheated. And at other times the magic of the wand is somehow too strong, as related by the southern Spaniard below. He has given a group of visiting foreigners the tour of the town, taken 
them on excursions etc., etc., in short, he has given them the full confianza treatment. Now the show is over, and they are back in their own countries:

Entonces empiezan a escribir cartas y quieren como mantener el contacto y llaman y tal, pero bueno, y tú como que ya no estás interesado, ya los has paseado, ya se han ido ... Vienen otros dentro de dos semanas, no estoy para atender a todo el mundo, oye ya se pueden dar por contentos los pobres, quedan como agradecidos no, y quieren como tengo un amigo en España, y no, no, mentira, no tienen nada.

Then they start writing letters and want to keep in contact; they call you, but you aren't interested any longer, you have entertained them, and they have gone back. There will be others in two weeks' time, and I cannot entertain the whole world. They will have to make do with what they have had, they will have to be thankful, but they think that they have a friend in Spain, but no, no, no, that's a lie, they don't have anything.

\section{Bibliography}

Bravo, D. 1996: La risa en el regateo: Estudio sobre el esilo comunicativo de negociadores españoles y suecos. Universidad de Estocholmo, Departamento de español y portugés.

Bravo, D. 1999: 'Imagen positiva' vs. 'imagen negativa'? Pragmática socio-cultural y componentes de face, Oralia. Análisis del discurso oral, vol. 2. Madrid: Arco Libros e Ilse, 155-184.

Briz, A. 1998: El español coloquial en la conversación. Esbozo de pragmagramática, Barcelona, Ariel Lingüística.

Goffman, E. 1967: Interactional Ritual: Essays on Face to Face Behaviour. Garden City, N.Y.: Anchor Books.

Gudykunst, W.B. 1985: A model of uncertainty reduction in intercultural encounters. In Journal of Language and Social Psychology 4, 79-98.

Gudykunst, W.B. 1988: Uncertainty and anxiety. In Kim Y.Y. \& Gudykunst W.B. (Eds.). In Theories in intercultural communication, 123-156. Newbury Park, CA: Sage

Gudykunst, W.B. \& Hall, B. 'J' 1994: Strategies for Effective Communication and Adaptation in Intergroup Contexts. In Daly J.A. \& Wiemann J.M., Strategic Interpersonal Communication, 225-271. LEA's Communication Series.

Gudykunst, W.B. \& Kim, Y.Y. 1992: Communicating with strangers (2n ed.). New York: McGraw-Hill.

Gudykunst, W.B. 1993: Towards a theory of effective interpersonal and intergroup communication. In Wiseman, R. \& Koester, J. (Eds.). In Intercultural communication competence, 33-71. Newbury Park: C.A., Sage. 


\section{4}

Hernández Flores, N. 2001: La cortesía en la conversación española de familiares y amigos. Universidad de Aalborg, Departamento de Lenguas y Estudios Interculturales.

Kjaerbeck, S. 2001: 'Nosotros los españoles' y 'los de afuera': un estudio de focus group sobre la identidad cultural y la formación de opinión. In Discurso y Sociedad, volumen 3 , número $1,43-74$.

Simmel, G. 1950: The Stranger. In Wolff, K., The Sociology of George Simmel, New York: Free Press.

Stephan, W. \& Stephan, C. 1985: Intergroup anxiety. In Journal of Social Issues 41, 157-166.

Williamson, O.E. 1993: Calculativeness, Trust, and Economic Organizations. In Journal of Law and Economics, XXXVI (April). 